\title{
Abbreviations and conventions
}

A\&JO

Add.

AHR

Al. Cant.

Al. Oxon.

$A P C$

$B I H R$

$\mathrm{BL}$

Bodl.

CCC

CJ

$C S P D$

$C S P V$

CUL

Cust, 'Parliamentary elections'

ECCO

$\mathrm{ECHR}$

EEBO

Eg.

EHR
C.H. Firth and R.S. Rait (eds), Acts and

Ordinances of the Interregnum, 1642-1660 (3

vols, London, I9II)

Additional Manuscript

American Historical Review

John and J.A. Venn, Alumni Cantabrigienses (4 vols, Cambridge, 1922-54)

J. Foster, Alumni Oxonienses (4 vols, Oxford, I89I-92)

Acts of the Privy Council of England

Bulletin of the Institute of Historical Research

British Library, London

Bodleian Library, Oxford

M.A.E. Green (ed.), Calendar of the Proceedings

of the Committee for Compounding, 1643-1660

(5 vols, London, I889-92)

Journals of the House of Commons

Calendar of State Papers Domestic

Calendar of State Papers Venetian

Cambridge University Library

Richard Cust, 'Parliamentary elections in

the I620s: the case of Great Yarmouth',

Parliamentary History, II (I992), I79-9I

Eighteenth Century Collections Online

Economic History Review

Early English Books Online

Egerton Manuscript

English Historical Review

Fletcher, 'National and local' Anthony Fletcher, 'National and local

xii 
FSL

GA

GL

$\mathrm{HEH}$

HJ

HLQ

$H M C$

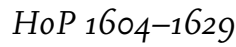

$H R$

$J B S$

KHLC

Lake and Pincus (eds),

Public Sphere

Lans.

LJ

LMA

LPL

Millstone, Manuscript

Circulation

n.d.

n.p.

$O D N B$

PQP

PCSM

Peacey, Print and Public Politics

$\mathrm{PH}$

Procs 1626

RO

Russell, Parliaments

Sharpe, 'Communication' awareness in the county communities', in

H. Tomlinson (ed.), Before the English Civil

War (Basingstoke, I983), I5I-74

Folger Shakespeare Library, Washington DC

Gloucestershire Archives

Guildhall Library

Henry E. Huntington Library, San Marino

Historical Journal

Huntington Library Quarterly

Historical Manuscripts Commission

Andrew Thrush and John P. Ferris (eds), The

History of Parliament: The House of Commons, 1604-1629 (6 vols, Cambridge, 20I0)

Historical Research

Journal of British Studies

Kent History and Library Centre, Maidstone

Peter Lake and Steven Pincus (eds), The

Politics of the Public Sphere in Early Modern

England (Manchester, 2007)

Lansdowne Manuscript

Journal of the House of Lords

London Metropolitan Archives

Lambeth Palace Library

Noah Millstone, Manuscript Circulation and

the Invention of Politics in Early Stuart England

(Cambridge, 20I6)

no date of publication

no place of publication

Oxford Dictionary of National Biography (online

edn, 2004-)

Past and Present

Publications of the Colonial Society of

Massachusetts

Jason Peacey, Print and Public Politics in the

English Revolution (Cambridge, 20I3)

Parliamentary History

William B. Bidwell and Maija Jansson (eds), Proceedings in Parliament 1626 (4 vols, New

Haven, I991-96)

Record Office

Conrad Russell, Parliaments and English

Politics, 1621-1629 (Oxford, I979)

Kevin Sharpe, 'Crown, Parliament and

locality: government and communication in 
SP

STC

TNA

TRHS

TWAS early Stuart England', EHR, Ior:399 (1986), $32 \mathrm{I}-50$

State Papers

Short Title Catalogue

The National Archives, Kew

Transactions of the Royal Historical Society

Tyne and Wear Archive Service,

Newcastle-upon-Tyne

All dates used are Old Style unless otherwise indicated, but the New Year is taken to begin on I January rather than 25 March. Original spelling has been retained throughout except that contractions have been expanded.

Unless otherwise stated, London is the place of publication for works printed before I750. 